To this end, after demobilisation, he enrolled as a student at University College Hospital and qualified MB, BS (Lond) in 1952. As soon as possible he began his psychiatric training and in 1957 he passed the Diploma of Psychological Medicine, and then in 1971 he was elected MRCPsych, proceeding FRCPsych in 1976.

But it was at the Maudsley where Skynner, owing undoubtedly to the powerful influence of the distinguished émigrépsychiatrist, Dr S. H. Foulhes, found his feet and began to shape his future.

Thus, in 1959, Skynner, together with fellow disciples of their guru, Dr Foulhes, founded the Group Analytic Practice. A logical development was the emergence of the Institute of Group Analysis for the specific purpose of giving training in group therapy. However, it was Skynner himself who in 1977 founded the Institute of Family Therapy and chaired it for the next 2 years.

The important posts he successfully filled were senior tutor (psychotherapy) at the Institute of Psychiatry, honorary assistant consultant psychiatrist at Bethlem Royal and Maudsley Hospital and physician in charge of the Department of Psychiatry at Queen Elizabeth Hospital for Children, London.
But, even if all else failed, Skynner will be remembered for his prolific writing, particularly for two of his books; Institutes and How to SurviveThem (1989) and Families and How to SurviveThem (1975). The latter was co-written with the actor John Cleese of Fawlty Towers fame and proved to be a blockbuster: it sold 353000 copies and was translated into 10 languages.

Robin Skynner married twice: the first in 1948 to Geraldine Foley was dissolved in 1959. That same year he married Prudence Fawcett, who died in 1987. He leaves a son and a daughter of his second marriage.

Henry H. Rollin

\title{
miscellany
}

\section{Independent Psychiatrists Group}

The Independent Psychiatrists Group has been established by a number of doctors working substantially in private clinical or medico-legal practice to assist those who are not working in managed organisations to meet continuing medical education (CME) requirements and to represent the views of such doctors, in particular, with respect to CME and revalidation. Monthly educational meetings have been arranged in London for those who are able to attend and occasional meetings in
London and the North of England are being planned. The secretary of the group is Dr Duncan Veasey and he would be delighted to hear from any other Member or Fellow of the College who would like to join the group. Dr Veasey can be contacted on tel no 01305852457.

\section{forthcoming events}

\footnotetext{
The Clinical Governance Support

Service (CGSS) at The Royal College of

Psychiatrists' Research Unit is organising

Clinical Governance in Forensic

Mental Health, an event taking place on

13 June 2001 in London. For information about this event please contact CGSS on tel no 0207227 0829. The College Research Unit is also organising a 1-day multi-professional conference entitled

Old Age Psychiatric Day Hospitals: Current Developments and Messages from Latest Research. The conference will be held on 21 June 2001 and further information can be obtained from Jo Baker (tel: 0207227 0827; e-mail: joanne1.baker@virgin.net).
}

Gardiner-Caldwell Communications and the Institute of Neurology are the organisers of a meeting entitled

Seizures, Affective Disorders and Anticonvulsant Drugs. The meeting will take place on 22 June 2001 in Berlin, Germany. For further information please visit the website address http:// www.sadad2001.com or contact Jackie Ashmenall, Conference Coordinator, St Aidan, Ealing Green, Ealing, W5 5EN (tel: 0207829 8743; fax: 0207278 3053; e-mail: jashmenall@yahoo.com).
The UK network of the International Society for the Psychological Treatments of Schizophrenia and other Psychoses (ISPS) has organised a multi-disciplinary conference entitled Psychosis - The Therapeutic Relationship in Individuals and Families Affected by Psychosis. Taking place on 13-14 September 2001 at the University of Reading, this conference will explore the nature of the therapeutic relationship in the many approaches to persons with psychoses in its different phases and contexts. The conference is for all psychiatrists and other mental health professionals. Continuing professional development approval has been given. For further information please contact Bell Howe Conferences (ISPS) (tel/fax: 0115846 9086; e-mail: ISPS@bellhowecon.demon.co.uk).

The University College London Department of Psychiatry and Behavioural Sciences is inviting applications for a 2-year part-time MSc in Psychiatric Theory and Research starting in October 2001. The MSc is intended for senior house officers and specialist registrars in psychiatry and aims to provide a firm grounding in research methodology. In the first year students will be required to attend two afternoons per week and in the second year students will conduct a research project under supervision and submit a 15000 -word dissertation. Places on the course are limited to 15 students, so early application is advisable. For an application form and prospectus please contact Linda Dutton, Course Administrator (tel: 0207679 9475; e-mail: l.dutton@ucl.ac.uk).

\section{The 17th World Congress of Social}

Psychiatry will be held in Agra, India, on 27-31 October 2001. Formally sponsored by the World Health Organization, World Psychiatric Association, National Institute on Drug Abuse and National Human Rights Commission of India, the congress promises high quality presentations and scientific sessions by eminent speakers in the field of psychiatry and allied areas. The registration form, abstract form and accommodation form can be downloaded from the congress website at http:// www.17thwaspcongress.com. For congress brochures please contact the 17th WASP Congress Secretariat, Institute of Human Behaviour and Allied Sciences (IHBAS), G. T. Road, Dilshad Garden, PO Box 9520, Delhi 110095, India (tel: +91 11 2114025; fax: +91 112299227 e-mail:wasp_congress@vsnl.com).

\section{corrigenda}

On page 114 of the paper by Cree et al (Psychiatric Bulletin, March, 25, 114-116), in the 'Results' section of the 'Abstract', the final sentence should read:

"The most effective treatment may be a combination of terazosin and benzatropine."

On page 155 of the correspondence column, at the end of the letter entitled "The limited value of the annual physical health examination in long-term secure care" (Psychiatric Bulletin, April, 25, 154-155) the name of the author David Brabiner, Specialist Registrar in Forensic Psychiatry, was omitted. 